\title{
EFEKTIVITAS EDUKASI GRUP TERHADAP MANAGEMENT SELF CARE FATIGUE PADA KLIEN END STAGE RENAL DISEASE (ESRD) YANG MENJALANKAN HEMODIALISA
}

\author{
Kgs. M. Faizal ${ }^{1}$, Busjra M.Nur ${ }^{2}$, Fitrian Rayasari ${ }^{3}$ \\ e-mail: muhammadfaizal@stikescitradelima.ac.id
}

\begin{abstract}
ABSTRAK
Penyakit ginjal kronik adalah kerusakan ginjal progresif yang berakibat fatal dan ditandai dengan uremia (urea dan limbah nitrogen lainnya beredar dalam darah serta komplikasinya jika tidak dilakukan dialisis atau transplantasi ginjal). Hemodialisa masih sebagai terapi utama dalam penanganan gangguan ginjal kronik, namun memiliki dampak bervariasi, salah satunya berupa fatigue. Fatigue merupakan salah satu masalah keperawatan, sehingga perlu diatasi dengan metode management self care fatigue. Penelitian ini bertujuan mengetahui efektivitas edukasi grup terhadap management self care fatigue klien gagal ginjal kronik yang menjalani terapi hemodialisa. penelitian ini menggunakan desain quasi eksperiment pre and post test with control group, dengan jumlah sampel sebanyak 26 responden yang terdiri dari kelompok intervensi dan kelompok kontrol. Rata-rata management self care fatigue setelah perlakuan pada kelompok intervensi mengalami peningkatan, diperoleh hasil adanya perbedaan yang signifikan rata-rata management self care fatigue antara kelompok intervensi dan kelompok kontrol setelah di lakukan edukasi grup $(p=0,001)$. Tidak ada hubungan antara jenis kelamin $(p=0,213)$, usia $(p=0,477)$, tingkat pendidikan $(p=0,063)$ dengan management self care fatigue. Sedangkan management self care fatigue akan meningkat setelah dilakukan edukasi grup dan dikontrol oleh pengetahuan $(p=0,000)$. Edukasi grup dapat meningkatkan management self care fatigue pada klien menjalani hemodialisia, diharapkan dapat diterapkan di tatanan klinik terutama klien yang mengalami keluhan yang sama seperti fatigue.
\end{abstract}

Kata Kunci : ESRD, Edukasi Grup, Management Sef Care Fatigue

\section{THE EFFECT OF EDUCATION GROUP ON MANAGEMENT SELF CARE FATIGUE OF PATIENT END STAGE RENAL DISEASE (ESRD) UNDERGOING HEMODIALYSIS}

\begin{abstract}
ABSTRACK
Chronic Renal Failure (chronic kidney disease) is a progressive renal damage which is harmful and the characterized is uremia (urea and other nitrogenous waste circulating in the blood and cause complications if not dialysis or a kidney transplant). Haemodialysis is primary therapy in the treatment of chronic kidney disease, but it has varied effects, which of fatigue. Fatigue is nursing problems, that need to be addressed by of self-care Management of fatigue method. The objektive this research is to determine effectiveness of education group on self care Fatigue Management of clients with chronic renal failure undergoing hemodialysis therapy. This research uses quasi experimental pre and post test with control group, with a total sample 26 respondents consisting of the intervention group and the control group. The average self-care Management of fatigue after treatment at the intervention group had increased, the result of significant differences in the average self-care Management of fatigue between the intervention group and the control group after doing education group $(\mathrm{p}=0.001)$. There is not relationship between the sexes $(\mathrm{p}=0.213)$, age $(\mathrm{p}$ $=0.477)$, education level $(\mathrm{p}=0.063)$ with self care Management of fatigue. Management of self care while fatigue will be increased after education group and controlled by knowledge $(\mathrm{p}=0.000)$. Education Group Management of self care can improve fatigue at clients undergoing haemodylisis, expected to be applied in clinic especially clients who have probleme fatigue.
\end{abstract}

Keywords:ESRD, Education Group, Management Sef Care Fatigue 


\section{PENDAHULUAN}

End Stage Renal Disease (ESRD) adalah kerusakan ginjal progresif yang berakibat fatal dan ditandai dengan uremia (urea dan limbah nitrogen lainnya beredar dalam darah serta komplikasinya jika tidak dilakukan dialisis atau transplantasi ginjal). Fungsi renal menurun karena produk akhir metabolisme protein tertimbun dalam darah, sehingga mengakibatkan terjadinya uremia dan mempengaruhi seluruh sistem tubuh, semakin banyak timbunan produksi sampah maka gejala semakin berat (Nursalam, 2011).

WHO memperkirakan di seluruh dunia, jumlah klien $E S R D$ yang menerima terapi hemodialisa diperkirakan lebih dari 1,4 juta, dengan kejadian tumbuh sekitar 8\% pertahun (WHO, 2011). PENEFRI (Persatuan Nefrologi Indonesia) melaporkan jumlah klien ESRD di Indonesia terus meningkat dari tahun ke tahun, pasien baru pada tahun 2013 sebanyak 15.128 orang dan tahun 2014 sebanyak 17.193 orang. Hal ini menunjukan peningkatan sebanyak $13 \%$. Sedangkan pasien aktif melakukan hemodialisa pada tahun 2013 sebanyak 9.396 orang dan tahun 2014 sebanyak 11.689 orang. Ini juga menunjukan peningkatan sebanyak 24\% (Penefri, 2014)

Prevalensi ESRD berdasarkan diagnosis dokter di Indonesia sebesar 0,2 persen. Prevalensi tertinggi di Sulawesi Tengah sebesar $0,5 \%$, diikuti Aceh, Gorontalo, dan Sulawesi Utara masing-masing $0,4 \%$. Sementara Nusa Tenggara Timur, Sulawesi Selatan, Lampung, Jawa Barat, Jawa Tengah, DI Yogyakarta, Jawa Timur masing-masing 0,3\% dan Bangka Belitung sebesar 0,1\% (Riskesdas, 2013). Dampak gagal ginjal adalah ketidakmampuan ginjal dalam melakukan membuang produk metabolisme dalam tubuh sehingga diperlukan terapi pengganti ginjal. Fasilitas layanan kesehatan yang diberikan kepada klien gagal ginjal untuk terapi pengganti ginjal di Unit Hemodialisa adalah layanan Hemodialisa 78\%, Transplantasi 16\%, Continuous Ambulatory Peritoneal Dialysis (CAPD) 3\%, dan Continuous renal replacement therapy (CRRT) 3\%. Saat ini yang menjadi terapi utama dalam penanganan pasien ESRD adalah hemodialisa (Sudoyo, et al., 2006).

Hemodialisa adalah suatu prosedur dimana kotoran dibuang dari darah melalui ginjal buatan yaitu mesin hemodialisa. Hemodialisa bertujuan untuk mengambil zat-zat nitrogen yang toksik dari dalam darah, mempertahankan keseimbanagan cairan, elektrolit dan asam basa serta mengembalikan manifestasi kegagalan ginjal yang irreversibel, tetapi tidak menyembuhkan ESRD (Smeltzer, 2010). Prevalensi klien melakukan hemodialisa secara rutin pada tahun 2014 di Indonesia sebanyak 95\% (Penefri, 2014). Hemodialisa masih sebagai terapi utama dalam penanganan gangguan ginjal kronik, namun memiliki dampak bervariasi, salah satunya berupa fatigue. Fatigue merupakan salah satu masalah keperawatan. Menurut NANDA (North American Nursing Diagnosis Association) fatigue merupakan keletihan terus menerus dan penurunan kapasitas untuk kerja fisik dan mental pada tingkat yang lazim (Herdman, 2015).

Fatique adalah perasaan subjektif yang tidak menyenangkan berupa kelelahan, kelemahan, penurunan energi, dan merupakan keluhan utama pasien dengan hemodialisa. Fatigue disebabkan oleh faktor fisiologis, termasuk akumulasi sampah metabolik, konsumsi energi yang abnormal dan kehilangan nafsu makan. Lebih lanjut Fatigue juga disebabkan oleh karena inaktifitas fisik (kebiasaan yang menetap) dan distress emosional (Horigan, 2012). Fatigue memiliki prevalensi yang tinggi pada populasi pasien hemodialisa. Simptom fatigue dialami $82 \%$ sampai $90 \%$ pada klien yang menjalankan hemodialisa (Kring, 2009). Penelitian yang dilakukan Ferry (2015) kepada klien yang menjalani hemodialisa terhadap kemandirian kebutuhan fisik dan psikologis, dimana klien ESRD mengalami kemunduran secara fisik: merasa lelah, tidak bersemangat, kurangnya konsentrasi sedangkan secara psikologis: merasa tidak berguna dengan kondisi kesehatan yang dirasakan saat ini. Fatigue dikategorikan menjadi fatigue fisik dan fatigue mental (Horigan, 2012). Fatigue fisik adalah kurangnya kekuatan fisik dan energi yang membuat mereka merasa lemas, 
lelah seperti tidak bertenaga. Fatigue mental adalah kelelahan mental yang membuat klien merasa bosan dalam menjalani terapi hemodialisa secara terus menerus dan merasa tidak memiliki harapan hidup. Fatigue memiliki gejala non-spesifik dan tak terlihat, dan merupakan fenomena yang kurang dipahami oleh para profesional kesehatan seperti perawat. Fatigue sebagai keadaan kontinue antara kelelahan dan kepenatan yang pada akhirnya berujung dengan penurunan vitalitas dan energi (Mollaoglu, 2009).

Fatigue pada pasien ESRD yang menjalankan hemodialisa dapat disebabkan oleh kurangnya kebutuhan nutrisi akibat dari penurunan nafsu makan. Penelitian yang dilakukan Bossola (2010) terhadap 76 responden didapatkan hasil bahwa kurang nafsu makan memiliki hubungan yang signifikan terhadap kelelahan. Gangguan tidur juga merupakan penyebab terjadinya fatigue. Penelitin yang dilakukan McCann dan Boore (2010) terhadap 39 responden didapatkan hasil bahwa kualitas tidur yang kurang baik memiliki hubungan yang signifikan terhadap kelelahan. Penelitian yang dilakukan Jhamb et, al,. (2008) menemukan bahwa kondisi fatique pada pasien hemodialisa dapat menyebabkan konsentrasi menurun, malaise, gangguan tidur, gangguan emosional, dan menurunkan kemampuan pasien dalam melakukan aktivitas sehari - harinya, sehingga pada akhirnya dapat menurunkan kualitas hidup pasien hemodialisa. Penatalaksanaan fatigue yang tepat dapat mencegah penurunan kualitas hidup pasien yang menjalankan terapi hemodialisa (Black \& Hawks 2014).

Profesi perawat merupakan bagian dari tenaga kesehatan mempunyai peranan penting dalam membantu untuk menghilangkan atau menurunkan tingkat fatigue pada klien hemodialisa. Intervensi keperawatan terhadap fatigue merupakan intervensi mandiri dari profesi keperawatan, dimana seorang perawat diharapkan mampu mengembangkan berbaga intervensi untuk mengatasi fatigue. Intervensi keperawatan yang dapat dikembangkan untuk mengatasi fatigue adalah management self care fatigue. Horigan (2012) menyampaikan intervensi keperawatan untuk mengatasi fatigue pada pasien ESRD yang menjalankan terapi hemodialisa adalah pengaturan aktivitas, pemenuhan nutrisi yang baik, istirahat yang cukup dan mendapatkan dukungan sosial. Management self care pada klien yang menjalani hemodialisa merupakan usaha positif klien untuk menemukan dan berpartisipasi dalam pelayanana kesehatan. Tujuan management self care untuk mengoptimalkan kesehatan, mencegah komplikasi, mengontrol gejala, menyusun sumber - sumber pengobatan, meminimalisir gangguan dalam penyakit yang dapat mengganggu kehidupannya (Curtin, 2001).

Pengetahuan yang baik tentang management self care fatigue dapat memberikan pemahaman kepada klien untuk dapat melakukan tindakan secara mandiri dalam mengatasi fatigue. Pengetahuan adalah hasil penginderaan manusia, atau hasil tahu seseorang terhadap objek melalui indera yang dimilikinya (mata, hidung, telinga dan sebagainya). Dengan sendirinya, pada waktu penginderaan sampai menghasilkan pengetahuan tersebut sangat dipengaruhi oleh intensistas perhatian dan persepsi terhadap objek. Pengetahuan tentang kesehatan adalah mencakup apa yang diketahui oleh seseorang terhadap cara-cara memelihara kesehatan (Notoatmodjo, 2010). Penelitian yang dilakukan Triana (2015) menemukan bahwa pengetahuan mempunyai hubungan signifikan $\mathrm{p}=0,003$ dengan management self care kram otot pada pasien yang menjalankan hemodialisa, dimana pengetahuan yang baik dapat menjadi dasar klien melakukan tindakan yang baik pula. Untuk itu perawat perlu memperhatikan pengetahuan dan kemampuan pasien dalam menerima informasi, salah satu peran perawat yang dapat dilakukan adalah memberikan edukasi kepada klien.

Edukasi merupakan intervensi keperawatan yang bertujuan meningkatkan kemapuan klien. Edukasi kesehatan adalah suatu proses mendidik individu/ masyarakat agar dapat memecahkan masalah kesehatan yang dihadapinya. Tujuan dari edukasi dapat memberikan pengalaman yang berupa pengetahuan tentang kesehatan kepada klien yang nantinya akan mengubah sikap dan perilaku yang dapat meningkatkan status 
kesehatan (Sarwono, 2009). Penelitian yang dilakukan Ferry (2015) tentang edukasi terhadap klien menjalankan hemodialisa menemukan bahwa ada perbedaan yang siginifikan kemandirian pemenuhan kebutuhan fisik sebelum dan sesudah dilakukan edukasi dengan nilai $p$ value 0,016. Dapat disimpulkan bahwa edukasi memiliki pengaruh terhadap kemandirian pemenuhan kebutuhan fisik pada klien hemodialisa. Ada beberapa metode dalam memberikan edukasi yaitu metode ceramah, diskusi kelompok, panel, forum panel, permainan peran, symposium, dan demonstrasi, dimana masing - masing metode tersebut memiliki keunggulan. Penelitian yang dilakukan Shrader et al (2013), Wulp et al (2012) menemukan program edukasi pada klien diabetes meletus yang dilakukan secara kelompok efektif dalam pengontrolan gula darah. Edukasi kelompok berfokus pada penyelesaian masalah dan manajemen diri, terdapat banyak ide yang muncul serta sharring pengalaman, berlatih keterampilan berkomunikasi dan memberikan dukungan sosial. Penelitian yang dilakukan Relawati (2015) tentang tentang pengaruh self help group terhadap kualitas hidup pasien hemodialisa, yang menekankan diskusi kelompok dan sharring didapatkan hasil pvalue $=0,001$.

Meningkatkan kemampuan management self care fatigue pada klien ESRD yang menjalankan terapi hemodialisa dapat dilakukan dengan cara edukasi grup. Klien yang menjalankan hemodialisa merupakan kelompok yang bertemu sesuai jadwal yang telah ditentukan saat melakukan terapi hemodialisa di rumah sakit. Pada saat sesama klien memiliki keluhan yang sama terhadap terapi hemodialisa yang dijalankan, mereka melakukan sharing atau bertukar pengalaman dalam mengatasi keluhan tersebut. Ini merupakan potensi yang dapat membantu perawat dalam melakukan intervensi keperawatan yang menekankan pada kelompok yang sama yaitu klien ESRD yang menjalankan terapi hemodialisa.

Rumah Sakit Umum Daerah Sungailiat Kabupaten Bangka merupakan salah satu rumah sakit yang menyediakan pelayanan hemodialisa dengan kapasitas 12 tempat tidur. Klien ESRD yang menjalankan terapi hemodialisa pada tahun 2013 berjumlah 301 klien, tahun 2014 berjumlah 523 klien, sedangkan pada tahun 2015 berjumlah 552 klien. Data tersebut menunjukan adanya peningkatan kebutuhan pasien terhadap pelayanan hemodialisa sebesar $83 \%$ dari 2 tahun terakhir. Hasil Pengamatan yang dilakukan peneliti di unit hemodialisa rumah sakit tersebut terhadap 42 klien didapatkan bahwa 28 klien (67\%) mengalami fatigue. Hasil wawancara langsung kepada klien didapatkan hasil bahwa merasakan kelelahan pada saat beberapa jam setelah dilakukan hemodialisa dan saat melakukan aktivitas yang rutin (aktivitas yang biasa dilakukan). Upaya yang telah dilakukan oleh sebagian klien berdasarkan informasi dari perawat di Unit Hemodialisa sebanyak 50\% klien mengatasi keluhan fatigue dengan cara membatasi aktivitas dan tidur yang cukup. Klien mengatakan belum memahami apa itu kelelahan dan bagaimana cara mengatasi kelelahan yang dialami, saat ini hanya diberikan informasi secara lisan oleh perawat tentang bagaimana mengatasi kelelahan. Informasi yang didapatkan pada

Tabel 5.7

Analisis Rata-rata Skor Management Self Care Fatigue pada Kelompok Intervensi dan Kelompok Kontrol Sebelum dan Sesudah Perlakuan di RSUD Sungailiat Kabupaten Bangka Tahun 2016

\begin{tabular}{lccccccc}
\hline \multicolumn{1}{c}{ Variabel } & n & Mean & SD & $\begin{array}{c}\text { Rerata } \\
\mathbf{9 5 \%} \text { CI }\end{array}$ & t & df & $\begin{array}{c}\boldsymbol{p} \\
\text { value }\end{array}$ \\
\hline $\begin{array}{l}\text { Management Self Care } \\
\text { Fatigue Pre }\end{array}$ & & & & & & \\
$\begin{array}{l}\text { Intervensi } \\
\text { Kontrol }\end{array}$ & 13 & 35,46 & 5,882 & $-6,366-$ & $-0,794$ & 24 & 0,435 \\
\hline $\begin{array}{l}\text { Management Self Care } \\
\text { Fatigue Post }\end{array}$ & 13 & 33,69 & 5,468 & 2,828 & & & \\
$\begin{array}{l}\text { Intervensi } \\
\text { Kontrol }\end{array}$ & 13 & 39,62 & 7,042 & $-10,350-$ & $-2,448$ & 24 & 0,022 \\
& 13 & 34,00 & 4,340 & 0,880 & & & \\
\hline
\end{tabular}


Tabel 5.8

Analisis Rata-rata Skor Management Self Care Fatigue Sebelum dan Sesudah Perlakuan pada Kelompok Intervensi dan Kelompok Kontrol di RSUD Sungailiat Kabupaten Bangka Tahun 2016

\begin{tabular}{lccccccc}
\hline \multicolumn{1}{c}{ Variabel } & n & Mean & SD & $\begin{array}{c}\text { Rerata } \\
\mathbf{9 5 \%} \text { CI }\end{array}$ & t & Df & $\begin{array}{c}\boldsymbol{p} \\
\text { value }\end{array}$ \\
\hline Intervensi & & & & & & & \\
Sebelum & 13 & 35,46 & 5,882 & $-6,156-$ & $-4,521$ & 12 & 0,001 \\
Sesudah & 13 & 39,62 & 7,042 & 2,152 & & & \\
\hline Kontrol & 13 & 33,69 & 5,468 & $-1,394-$ & $-0,617$ & 12 & 0,549 \\
Sebelum & 13 & 34,00 & 4,340 & 0,778 & & & \\
Sesudah & & & &
\end{tabular}

saat perawat melakukan tindakan

hemodialisa tetapi belum dilakukan secara terstruktur atau melalui sebuah program. Edukasi grup dapat menjadi alternatif dengan menekankan diskusi sesama klien ESRD yang menjalankan terapi hemodialisa.

\section{Metode Penelitian}

Desain penelitian yang digunakan pada penelitian ini adalah dengan desain quasi eksperiment pre and post test with control group. Penelitian yang di laksanakan adalah dengan cara mengetahui efek perlakuan pada kelompok subjek yang diberikan intervensi tekhnik edukasi grup dengan kelompok kontrol.

\section{Hasil Penelitian}

Penyajian analisa data statistik yang fatigue pada klien ESRD yang menjalankan terapi hemodialisa. Gambaran hasil analisis statistik pada penelitian ini adalah sebagai berikut:

Pada tabel 5.7 menunjukkan rata-rata skor management self care fatigue sebelum dilakukan edukasi grup pada kelompok intervensi adalah 35,46 (SD = 5,882). Sedangkan rata-rata skor management self care fatigue sebelum dilakukan edukasi grup pada kelompok kontrol adalah 33,69 dengan $(\mathrm{SD}=5,468)$.

Pada tabel 5.8 menunjukkan rata-rata skor management self care fatigue pada kelompok intervensi sebelum dilakukan edukasi grup adalah $35,46(\mathrm{SD}=5,882)$.

Tabel 5.9

Analisis Rata-rata Selisih Skor Management Self Care Fatigue Sesudah dilakukan Edukasi Grup Pada Kelompok Intervensi dan kelompok Kontrol di RSUD Sungailiat Kabupaten Bangka Tahun 2016

\begin{tabular}{lccccccc}
\hline \multicolumn{1}{c}{ Variabel } & n & Mean & SD & $\begin{array}{c}\text { Rerata } \\
\mathbf{9 5 \%} \text { CI }\end{array}$ & t & df & $\begin{array}{c}\boldsymbol{p} \\
\text { value }\end{array}$ \\
\hline Selisih & & & & & & & \\
Intervensi & 13 & 4,15 & 3,313 & $-6,004-$ & $-3,679$ & 24 & 0,001 \\
Kontrol & 13 & 0,31 & 1,797 & 1,689 & & & \\
\hline
\end{tabular}

ditampilkan meliputi penyajian analisa Sedangkan rata-rata skor management self univariat mendeskripsikan karakteristik responden, management self care fatigue, dan variabel konfounding. Penyajian berikutnya adalah penyajian bivariat yang menampilkan perbedaan nilai management self care fatigue pada kelompok intervensi dan kelompok kontrol dan pengaruh variabel konfonding terhadap management self care fatigue pada klien ESRD yang menjalankan terapi hemodialisa. Penyajian multivariat menampilkan analisis variabel yang paling berhubungan dengan management self care care fatigue sesudah dilakukan edukasi grup adalah 39,62 dengan ( $\mathrm{SD}=7,042)$. Hasil uji statistik didapatkan nilai $p=0,001$ maka dapat disimpulkan bahwa ada perbedaan yang signifikan antara management self care fatigue sebelum dan sesudah dilakukan edukasi grup pada kelompok intervensi. Pengukuran dilakukan dengan menggunakan uji statistik dependen $t$-test. 
Pada tabel 5.7 menunjukkan rata-rata skor management self care fatigue setelah dilakukan edukasi grup pada kelompok intervensi adalah 39,62 (SD = 7,042). Sedangkan rata-rata skor management self care fatigue setelah dilakukan perlakuan pada kelompok kontrol adalah 34,00 dengan $(\mathrm{SD}=4,340)$. management self care fatigue sesudah dilakukan edukasi grup selama observasi empat minggu adalah 39,62 dengan ( $\mathrm{SD}=$ 7,042 ). Hasil uji statistik didapatkan nilai $p$ $=0,001$ kurang dari nilai $\alpha=0,05$, sehingga dapat disimpulkan bahwa ada perbedaan yang signifikan antara management self care fatigue sebelum dan sesudah dilakukan

Tabel 5.10

Hasil Analisis Pemodelan Akhir Multivariat Variabel Independen dan Variabel Konfonding dengan Management Self Care Fatigue

\begin{tabular}{|c|c|c|c|c|}
\hline Variabel & R Square & B & SE & $p$ value \\
\hline MSCF & \multirow{2}{*}{0,605} & 13,449 & 3,933 & 0,002 \\
\hline Pengetahuan & & 2,101 & 0,346 & 0,000 \\
\hline
\end{tabular}

Pada tabel 5.8 menunjukkan rata-rata skor management self care fatigue sebelum dilakukan perlakuan pada kelompok kontrol adalah 33,69 $(\mathrm{SD}=5,468)$. Sedangkan ratarata skor management self care fatigue sesudah dilakukan perlakuan adalah 34,00 dengan $(\mathrm{SD}=4,340)$. Hasil uji statistik didapatkan nilai $p=0,549$ maka dapat disimpulkan bahwa tidak ada perbedaan yang signifikan antara management self care fatigue sebelum dan sesudah pada kelompok kontrol. Pengukuran dilakukan dengan menggunakan uji statistik dependen t-test.

Pada tabel 5.9 menunjukkan bahwa, perbedaan selisih skor management self care fatigue klien ESRD yang menjalani terapi hemodialisa pada kelompok intervensi rataratanya adalah 4,15 dengan $(\mathrm{SD}=3,313)$.

$$
\mathrm{Z}=\alpha+\beta 1 \mathrm{X} 1+\beta 2 \mathrm{X} 2 \ldots \ldots \ldots+\beta \mathrm{iXi}
$$

Management Self Care Fatigue $=13,449+$

$$
2,101 \text { Pengetahuan }=15,55
$$

Dengan demikian setiap skor management self care fatigue akan naik sebesar 2,101 setelah dikontrol oleh pengetahuan.

\section{PEMBAHASAN}

Hasil analisis menunjukkan rata-rata skor management self care fatigue kelompok intervensi sebelum dilakukan edukasi grup adalah 35,46 $(\mathrm{SD}=5,882)$, hasil penelitian ini skor management self care fatigue mengalami peningkatan rata-rata skor
Sedangkan pada kelompok kontrol rataratanya adalah 0.31 dengan $(\mathrm{SD}=1.797$ ). Uji statistik didapatkan hasil nilai $\mathrm{p}=0.001$ yang berarti ada perbedaan yang yang signifikan pada kedua kelompok tersebut.

Edukasi grup adalah percakapan yang direncanakan atau dipersiapkan di antara tiga orang atau lebih tentang topik tertentu dengan seseorang pemimpin. keunggulan metode grup ini adalah : 1) memberi kemungkinan untuk saling mengemukakan pendapat, 2) merupakan pendekatan yang demokratis, mendorong rasa kesatuan, 3) dapat memperluas pandangan atau wawasan, 4) problem kesehatan yang dihadapi akan lebih menarik untuk dibahas karena proses diskusi melibatkan semua anggota termasuk orang-orang yang tidak suka berbicara.

Proses edukasi grup dalam penelitian ini diikuti oleh 13 responden yang dibagi menjadi 3 kelompok. 2 kelompok dilakukan setelah hemodialisa masing - masing 4 klien dan 1 kelompok dilakukan sebelum hemodialisa sebanyak 5 klien. Edukasi grup berjalan dengan baik pada masing - masing kelompok, responden bersemangat dan ingin tau terhadap informasi yang diberikan. Edukasi grup menekankan sharring atau berbagi pengalaman pada setiap responden tentang cara mengatasi fatigue yang dialami. Banyak informasi yang didapatkan berdasarkan pengalaman masing - masing klien. 
Penggunaan metode diskusi kelompok atau edukasi grup menekan ketentuan berikut: peserta diberi kesempatan saling mengemukakan pendapat, problema dibuat menarik, peserta dibantu mengemukakan pendapatnya, problema perlu dikenal dan diolah, ciptakan suasana informasi, orang yang tidak suka bicara diberi kesempatan. Metode ini memiliki perbedaan dengan metode yang hampir mirip seperti panel dan forum panel, dimana metode tersebut menggunakan beberapa narasumber atau pemateri. Sedangkan metode kelompok hanya memiliki satu narasumber. Sehingga metode tersebut memerlukan moderator yang dapat membawa suasana diskusi lebih menarik (Maulana, 2009).

Proses edukasi grup merupakan salah satu strategi intervensi keperawatan yang dilakukan bersama - sama dengan klien melalui pembentukan suatu kelompok yang memiliki permasalahan yang sama. Beberapa kelompok di masyarakat dikembangkan sesuai dengan inisiatif dan kebutuhan masyarakat setempat. Intervensi pada edukasi grup berfokus pada penyelesaian masalah dan manajemen diri. Hal ini didukung oleh penelitian yang dilakukan Relawati, dkk (2015) tentang self help group terhadap kualitas hidup pasien hemodialisa didapatkan $\mathrm{p}$ value 0,001 , artinya ada pengaruh self help group terhadap kualitas hidup. Penelitian ini sama dengan metode secara edukasi grup. self help group (SHG) adalah suatu kelompok dimana setiap anggotanya saling berbagi masalah baik fisik maupun emosional. Tujuan SHG adalah agar setiap anggota kelompok bersosialisasi, menceritakan masalah yang mereka alami dan saling berbagi pengalaman kepada sesama anggota kelompok. Penelitian juga dilakukan pada kelompok klien diabetes melitus oleh Rosmawati (2013) didapatkan hasil bahwa terdapat perbedaan yang signifikan sebelum dan sesudah dilakukan edukasi grup. Penelitian yang dilakukan Shrader et al (2013), Wulp et al (2012) menemukan program edukasi pada klien diabetes meletus yang dilakukan secara kelompok efektif dalam pengontrolan gula darah. Edukasi kelompok berfokus pada penyelesaian masalah dan manajemen diri, terdapat banyak ide yang muncul serta sharing pengalaman, berlatih keterampilan berkomunikasi dan memberikan dukungan sosial.

\section{KESIMPULAN}

Terdapat perubahan yang signifikan rata-rata skor management self care fatigue klien gagal ginjal yang menjalani terapi hemodialisa antara kelompok intervensi sebelum dan sesudah di lakukan edukasi grup $(p=0,001)$. Tidak terdapat perbedaan yang signifikan rata-rata skor management self care fatigue pada klien ESRD yang menjalani terapi hemodialisa pada kelompok kontrol sebelum dan sesudah diberikan perlakuan $(p=0,549)$. Terdapat perbedaan yang signifikan rata-rata skor management self care fatigue pada klien ESRD yang menjalani terapi hemodialisa pada kelompok intervensi dan kelompok kontrol sesudah diberikan perlakuan $(p=0,022)$

\section{SARAN}

Mengembangkan model edukasi grup yang terbukti meningkatkan management self care fatigue khususnya pada klien ESRD dengan melakukan sosialisasi hasil-hasil penelitian melalui jurnal dan pelatihanpelatihan serta membuat program edukasi grup di unit hemodialisa.

Institusi pendidikan bisa menjadikan penelitian ini sebagai pengabdian masyarakat dengan cara mempublikasikan hasil penelitian kepada unit terkait seperti rumah sakit pemerintah dan rumah sakit swasta.

\section{DAFTAR PUSTAKA}

Black, J.M, Hawk, J.H. (2014). Keperawatan Medikal Bedah. Manajemen Klinis Untuk Hasil yang Diharapkan Edisi 8 Buku 2. Elsevier: Singapore.

Bossola, M., Luciani, G., Giungi, S., \& Tazza, L. (2010). Anorexia, fatigue, and plasma interleukin-6 levels in chronic hemodialysis patients. Renal Failure, 32(9), 1049-1054.

Curtin, Roberta Braun \& Donna L. Mapes. (2001). Health Care Management 
Strategies of Long Term Dialisis Supervivor. Nefrologi Nursing Jurnal.

Ferry. (2015). Pengaruh Edukasi pada Klien Hemodialisa Terhadap Kemandirian Dalam Pemenuhan Kebutuhan Fisik dan Psikologis. Jakarta: Tesis FIK UMJ

Herdman, T. Heater. (2015). Nanda International Inc. Diagnosis Keperawatan: Definisi \& Klasifikasi 2015 - 2017 edisi 10. Jakarta: EGC

Horigan, A.E. (2012). Fatigue in hemodialysis patients: a review of current knowledge. J Pain Symptom Manag 2012;44: 715-24.

Jhamb, M. (2008). Fatigue in PatientReceivingMaitanance dialysis: a review of definition, measurre and contributing factor. American Jurnal of Kidney Diasease.

Jhamb, M., Argyropoulos, C., Steel, J. L., Plantinga, L., Wu, A. W., Fink, N. E., et al. (2009). Correlates and Outcomes of Fatigue among Incident Dialysis Patients. Clinical Journal of the American Society of Nephrology.

Maulana, Heri D.J. (2009). Promosi Kesehatan. Jakarta: EGC

McCann, K., \& Boore, J. R. (2010). Fatigue in persons with renal failure who require maintenance haemodialysis. Journal of Advanced Nursing, 32(5), 1132-1142.

Medical Record Rumah Sakit Umum Daerah Sungailiat Kabupaten Bangka. Data Klien Menderita Gagal Ginjal Kronik Yang Menjalankan Terapi Hemodialisa.

Mollaoglu. (2009). Fatigue in People Undergoing Haemodialysis, Clinical Perspective: Dyalisis \& Transplantation, 38(6). Diperoleh dari http://www3.interscience.wiley.com.

Notoatmodjo, S. (2012). Metodologi Penelitian Kesehatan ISBN: 978-979518-984-8. Jakarta: Rineka Cipta
Nursalam. (2011). Asuhan Keperawatan pada Pasien dengan Gangguan Sistem Perkemihan. Jakarta: Salemba Medika.

PERNEFRI. (2014). 4th Report Of Indonesian Renal Registry. (online). www.pernefri-inasn.org. Diakses pada tanggal 15 Januari 2016.

Potter dan Perry. (2013). Fundamental of Nursing. Concepts, Process and Practice. $\left(8^{\text {th }}\right.$ ed) Imprint of Elsivier Inc: Mosby

Relawati, A., Hakimi, M., Huriah, T. (2015). Pengaruh Self Help Group Terhadap Kualitas Hidup Pasien Hemodialisa. Jurnal Ilmiah Kesehatan Keperawatan Volume 11 No. 3.

Riskesdas. (2013). Riset Kesehatan Dasar. Badan Penelitian dan Pengembangan Kesehatan Kementerian Kesehatan RI.

Rosmawati, M., Rohana, A.J., Manan W.A . (2013). The Evaluation Of SupportiveDevelopmental Nursing Program On Self-Care Practices Of Persons Bachok, Kelantan.

Smeltzer Suzenner. (2002). Buku Ajar Medikal Bedah. Vol 1 Ed. 8. Jakarta: EGC.

Smeltzer, S. C., Bare, B. G., Hinkle, J. L., \& Cheever, K. H. (2010). Brunner \& Suddarth's textbook of medical-surgical nursing (11th ed.). New York: Lippincott Williams \& Wilkins.

Sudoyo, A. W., Setiyohadi, B., Alwi, I., Simadibrata, M., \& Setiati, S. (2006). Buku ajar ilmu penyakit dalam. Edisi Ke4. Pusat Penerbitan Ilmu Penyakit Dalam FKUI, Jakarta, 1218-20.

(2009).Buku Ajar Ilmu Penyakit dalam Jilid II Edisi V. Jakarta: Pusat Penerbit Departement Ilmu Penyakit Dalam Fakultas Kedokteran Universitas Indonesia.

Triana, Neni. (2015). Hubungan Pengetahuan, Sikap Dan Praktek Dengan Manajement Self Care Kram Otot Pada 
Klien Yang Menjalani Hemodialisa.

FIK:UMJ.

WHO Indonesia. (2011). NCD Country

Profile 2011.

http://www.who.int/mmh/countries/idnen

.pdf. diakses pada tanggal 14 Januari 20016.

Wulp, V.D, de Leeuw J, Gorter K, Rutten G. 2012. Effectiveness of peer-led selfmanagement coaching for patients recently diagnosed with Type 2 diabetes mellitus in primary care: a randomized controlled trial. Diabetic Medicine: A Journal Of The British Diabetic Association. Available from: MEDLINE with Full Text, Ipswich, MA. 